(RESEARCH ARTICLE)

\title{
Climate change and coping strategies of Ibeno and Onna coastal fishing communities in Niger Delta, Nigeria
}

\author{
Vincent-Akpu Ijeoma Favour * \\ Hydrobiology and Fisheries Unit, Department of Animal and Environmental Biology, University of Port Harcourt.
}

Publication history: Received on 27 February 2020; revised on 12 March 2020; accepted on 14 March 2020

Article DOI: https://doi.org/10.30574/gscbps.2020.10.3.0051

\begin{abstract}
Ibeno and Onna are two coastal communities in Niger delta, Nigeria that are vulnerable to the effects of climate change. These communities face the risk of exposure due to water level rise, change in weather conditions and extreme weather events. The main means of livelihood in these communities is fishing which has been greatly impacted by climate change coupled with pollution that is endemic in Niger Delta. The perceived changes in weather conditions observed by the fishers in the two communities include changes in water depth, frequency and intensity of temperature and fluctuation in timing of rainfall. These perceived changes have contributed to increase in fishing efforts, fishing time, decrease in fish catch amongst others which in turn have affected their fishing livelihood. Thus there is a need to build up the resilience which starts from knowing their present coping strategies and proffering better coping strategies that will enhance resilience for the fishers.
\end{abstract}

Keywords: Ibeno; Onna; Niger Delta; Vulnerability; Fishers; Coastal community; Climate change

\section{Introduction}

The Niger Delta region is situated in the Gulf of Guinea on the west coast of Africa. Niger Delta, is home to 31 million people, occupying an area of about $75,000 \mathrm{~km}^{2}$ and which makes up $7.5 \%$ of Nigeria's land mass [1, 2]. It has the largest wetland in Africa with about 20,000sq/ km; a coastline of about $450 \mathrm{~km}$; and is located in the Atlantic coast of Southern Nigeria [3, 4, 5, 6, 7]. Niger delta of Nigeria is the location of oil and gas exploration and production in Nigeria. The impacts from oil and gas activities in Niger Delta are immense, given their overall vulnerability in the face of combined effects from human activities and climate change. The coastal folks especially in Niger delta are faced with socioeconomic dysfunction associated with environmental effects of industrial projects and natural events. Increasingly, projects are being located on the coasts where transport advantages on water are more readily available for oil and gas production. Thus Fishing activities and coastal communities are competing with large companies for the very spaces where the fishers have their homes and make their living. This problem in the face of development have been a serious topic of discussion over time in Nigeria, but successive governments in the country have not been able to provide practical solutions. The problem has been compounded by the fast pace occurrences of these cumulative developments; poor enforcement of environmental law and growing unpredictable climate changes and other natural hazards.

Ibeno and ONNA are two coastal communities along Kwa Iboe River and are among the largest fishing settlements on Nigerian coast. Most of the dwellers no longer engage in active fishing or farming as a means of livelihood because of the degraded environment and climate change.

There is a need to build up the resilience of the dwellers at the coastal region who are majorly fishers especially where the land is bordered by water. Using Adger [8] definition, social resilience is the ability of groups or communities to cope with external stresses and disturbances as a result of social, political, and environmental change. For the coastal

\footnotetext{
* Corresponding author: Vincent-Akpu Ijeoma Favour
}

Copyright (C) 2020 Author(s) retain the copyright of this article. This article is published under the terms of the Creative Commons Attribution Liscense 4.0. 
communities, resilience will mean creating resilient aquatic systems, fishers and increase the sector's adaptive capacity. Resilience strategies are flexible; for these to be relevant, they should be sensitive to the community context where they will be adopted. To proffer solutions to the problems or enhancing community resilience in coastal communities, it is important we highlight some of the challenges and existing coping strategies used by the coastal communities. A survey of human attributes and perception was carried out to assess the coping strategies employed by fishers in two coastal communities in Niger Delta and constrains faced in their livelihood. From the survey, the present coping strategies of the fishers were known, better coping strategies that will enhance resilience for the fishers will be given and recommendation to the government on best interventions.

\section{Material and methods}

\subsection{Study area}

Ibeno is located in the south east of Nigeria with Coordinates: $4.56^{\circ} \mathrm{N} 7.97^{\circ} \mathrm{E}$ and is a Local Government Area in Akwa Ibom State. Ibeno town lies on the eastern side of the Kwa Ibo River about 3 kilometres from the river mouth, and is one of the largest fishing settlements on the Nigerian coast. Ibeno lies in the Mangrove Forest Belt of the Niger Delta region of Nigeria; it is bounded in the West by Eastern Obolo local Government area, to the North by Onna, Esit Eket and Eket, to the South by the Atlantic Ocean (Figure 1).

Onna is located in the south east of Nigeria with Coordinates: $4.58^{\circ} \mathrm{N} 7.852^{\circ} \mathrm{E}$ and is also a Local Government Area in Akwa Ibom State (Figure 1). It is bounded by Eastern Obolo, Etinan, Mkpat Einin and Eket Local Government Areas. Onna's name is derives from an acronym of the three predominant clans that live in the area: Oniong Nnung, Ndem and Awa.

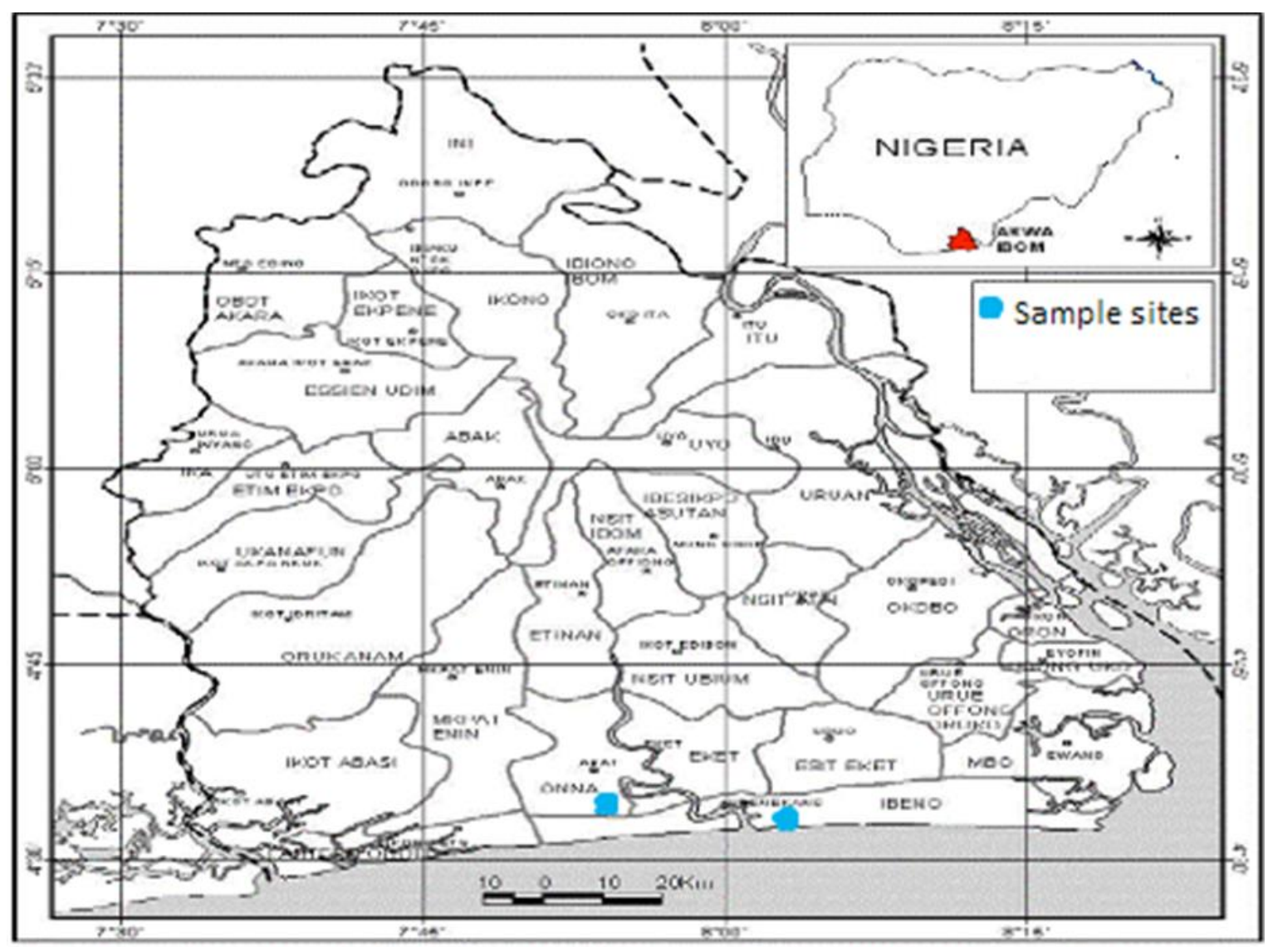

Figure 1 Map of sampling sites 


\subsection{Procedure for data collection}

Data were collected with the help of two assistants. The aim and objectives of the study were made clear to the assistants before going to the field. Preliminary visits were made which include consultation with the head fisherman on the essence of the study during which permission and support were obtained to carry out the study. The project adopted a case-study approach employing both qualitative and quantitative methods. Fieldwork was conducted from November 2014 to March 2015. There were two main stages to the research: household surveys and focus group discussions. Primary data were obtained through an approach that combined using questionnaire on household survey (50) and indepth interviews and discussions with the fishermen. The questionnaire was pretested for face and content validity. The survey had both closed and open-ended questions. The head of the households was selected for the survey mostly in the morning and evening, outside normal fishing hours. On occasions, surveys took place on landing sites as appropriate. The household questionnaire comprised of closed questions focused on the basic household characteristics, many components on the demography of the fishers; the perception and opinion on constrains to their livelihood; impact of climate change; vulnerability, and coping strategies in face of development projects and natural events.

Following the survey, two focus group discussions were conducted with an average of nine people each. The groups were selected randomly to provide an opportunity to discuss their knowledge on climate change, livelihood activity, and challenges they face. Secondary data were obtained through desktop review of available literatures.

Analysis was done using statistical package for social sciences (SPSS) version 20.0. Data collected were analyzed using descriptive methods and weighted mean score was used to make deductions which formed the basis for the research findings. The criterion mean equals to "the sum of items scale quantification figure" divided by "total number of quantification (Equation 1).

$\mathrm{X}_{\mathrm{w}}=\frac{\sum w x}{\sum x} \quad$ Equation 1

$\mathrm{Xw}=$ weighted arithmetic mean

$\mathrm{x}=$ values of the items

$\mathrm{w}=$ weight of the item.

The responses were measured in a ranking order of; $1=$ None, $2=$ Minor, $3=$ Major; $1=$ decrease, $2=$ no change, $3=$ increase. For two response questions like yes or no, regular and irregular, late and early, the positive ones have 2 while the negative ones have 1 . For the 3 point scale: $3+2+1=6 / 3=2.00$ while for the 2 point scale we have $2+1=3 / 2=1.5$. To arrive at a decision for three points scale, if the average weight is 2.00 , the decision is neutral, and at above 2.00 , the decision is positive, while below 2.00, the decision is negative. For the two points scale, above 1.5 , the decision is positive, at 1.5, neutral and below 1.5 is negative.

\section{Results and discussion}

\subsection{Demographic characteristics}

Gender, age, marital status, family type, family size, level of education, primary occupation, secondary occupation, housing type and weekly income were the demographic and socio-economic variables obtained (Table 1). All respondents were men which showed that women do not fish as a source of livelihood in these communities. Respondent distribution by age showed that over $90 \%$ and $85 \%$ of the respondents in Onna and Ibeno LGAs respectively were in their active working age of 20-59 years while most of them have extended family and large family size. The people from Ibeno were mostly fishers while those in Onna were able to diversify their occupation. Most of respondent are relatively poor with less than \#5000 (\$15) weekly incomes. 
Table 1 Demographic characteristics of Ibeno and Onna

\begin{tabular}{llll}
\hline Descriptions & Range & Ibeno (\%) & Onna (\%) \\
\hline Age & $20-39$ & 25 & 40 \\
& $40-59$ & 60 & 50 \\
Gender & $>60$ & 15 & 10 \\
Marital status & Male & 100 & 100 \\
& Female & 0 & 0 \\
Family type & Single & 25 & 20 \\
& Married & 70 & 70 \\
Family Size & Widowed & 5 & 10 \\
& Nuclear & 20 & 30 \\
Education & Extended & 80 & 70 \\
& $1-6$ & 10 & 25 \\
& $7-12$ & 75 & 55 \\
Occupation & $>13$ & 15 & 20 \\
& Non formal & 20 & 25 \\
Housing Type & Primary & 70 & 45 \\
& Secondary & 10 & 30 \\
& Trading & 0 & 20 \\
Weekly income(\#) & Fishing & 100 & 30 \\
& Farming & 0 & 50 \\
& Mud house & 25 & 0 \\
& Mud/galvanized & 50 & 60 \\
& Cement/galvanized & 25 & 40 \\
& & & \\
& 1000.00-2500.00 & 75 & 40 \\
& $2600.00-5000.00$ & 15 & 50 \\
& $>5000.00$ & 10 & 10 \\
\hline
\end{tabular}

Niger delta experiences two seasons which are the rainy and dry season, however, the respondent stated that these seasons are irregular with sporadic rain throughout the year. The fishers in the two communities agreed to have perceived changes in water depth, frequency and intensity of temperature and fluctuation in timing of rainfall but disagreed on duration of rainfall, frequency of flood and strong wind (Table 2). Unlike fishers in Ibeno, fishers in Onna disagreed in observing changes in intensity of wind, storms and flood. This could be attributed to the closeness of the fishers in Ibeno to the ocean where strong wind from the ocean are experienced. 
Table 2 Perceived effects of climate change in the communities

\begin{tabular}{lllllll}
\hline Questions & Ibeno & & & Onna & & \\
\cline { 2 - 7 } & Sum & Mean & Decision & Sum & Mean & Decision \\
\hline Temp. intensity & 52 & 2.60 & Agree & 44 & 2.20 & Agree \\
Intense heat & 52 & 2.60 & Agree & 44 & 2.20 & Agree \\
Water level & 52 & 2.60 & Agree & 40 & 2.00 & Agree \\
Duration of rainfall & 32 & 1.60 & Disagree & 38 & 1.90 & Disagree \\
Intensity of rainfall & 43 & 2.15 & Agree & 36 & 1.80 & Disagree \\
Frequency of flood & 35 & 1.75 & Disagree & 33 & 1.65 & Disagree \\
Intensity of flood & 54 & 2.70 & Agree & 33 & 1.65 & Disagree \\
Intensity of strong wind & 54 & 2.70 & Agree & 26 & 1.30 & Disagree \\
Frequency of strong wind & 33 & 1.65 & Disagree & 26 & 1.30 & Disagree \\
Intensity of storms & 40 & 2.00 & Agree & 34 & 1.70 & Disagree \\
Frequency of storms & 40 & 2.00 & Agree & 34 & 1.70 & Disagree \\
Frequency of hazards & 41 & 2.05 & Agree & 30 & 1.50 & Disagree \\
Intensity of hazards & 45 & 2.25 & Agree & 29 & 1.45 & Disagree \\
Rainfall Fluctuation & 34 & 1.70 & Agree & 40 & 2.00 & Agree \\
temperature fluctuation & 40 & 2.00 & Agree & 40 & 2.00 & Agree \\
timing of rainfall & 30 & 1.50 & No change & 32 & 1.60 & Disagree \\
\hline
\end{tabular}

People in Niger Delta remains poor and under developed, lacking all forms of social amenities and infrastructure, such as electricity, medical facilities, roads, decent shelter etc that could improve their adaptive capacity. Lack of fishing boat, fishing in distant location and high cost of fishing equipment were the major hindrances enumerated by the fishers in these communities. They stated that low level of education, lack money and little or no access to information that will help them and neglect by the government were constraints to their livelihood (Table 3 ).

Table 3 Perception of fishers on constraints, development and natural changes on their livelihood

\begin{tabular}{lllllll}
\hline Questions & Ibeno & & & Onna & \\
\cline { 2 - 7 } & Sum & Mean & Decision & Sum & Mean & Decision \\
\hline Lack of fishing boat & 33 & 2.70 & Agree & 53 & 2.65 & Agree \\
Fishing in distant location & 37 & 2.85 & Agree & 41 & 2.05 & Agree \\
High cost of fishing equipment & 40 & 3.00 & Agree & 60 & 3.00 & Agree \\
Lack of money & 38 & 2.90 & Agree & 60 & 3.00 & Agree \\
Low education & 30 & 2.50 & Agree & 52 & 2.60 & Agree \\
Poor access to climate information & 24 & 2.15 & Agree & 54 & 2.70 & Agree \\
Impact of climate change & 30 & 2.50 & Agree & 49 & 2.45 & Agree \\
Structural damage from storms & 28 & 2.40 & Agree & 46 & 2.30 & Agree \\
Neglect by government & 28 & 2.40 & Agree & 51 & 2.55 & Agree \\
High cost of transportation & 30 & 2.50 & Agree & 60 & 3.00 & Agree \\
Blockage of canal & 29 & 2.45 & Agree & 36 & 1.80 & Disagree \\
Overflowing banks & 31 & 2.55 & Agree & 30 & 1.50 & Disagree \\
Prevalence of sickness & 23 & 2.10 & Agree & 57 & 2.85 & Agree \\
Lack of landing site & 31 & 2.55 & Agree & 49 & 2.45 & Agree \\
Lack of basic infrastructures & 39 & 2.90 & Agree & 60 & 2.65 & Agree \\
Degradation of water and land & 40 & 3.00 & Agree & 58 & 2.05 & Agree \\
\hline
\end{tabular}


The consequences of the perceived effects of climate change are listed in Table 4; they include change in fishing distance, fishing frequency, and disappearing of species; structural damage from storms and overflowing banks. These fishing communities face similar problems and hindrances to their livelihood. Most of the respondents stated that they changed their occupation as a coping strategy because of degradation of natural habitat. Others diversified their means of livelihood to include hunting, farming and trading or migrate to the city for office job. Those that are fishing had to fish early, use better fishing gear or move a longer distance to get fish.

Most fishers complained that the oil companies explore oil and natural gas with no respect to their health, the quality of the environment and their livelihood. In addition to incessant oil spills and gas flaring, high-pressured pipelines are laid on the earth surface and at close vicinity to their homes. These result in environmental hazards, air pollution and rivers and creeks with seafood, fish and other resources contaminated. The fishers are vulnerable to environmental threats as they are often dependent on their immediate environment for survival. Environmental degradation most times implicates the peoples' right to survival and property.

In addition to environmental degradation, the Niger Delta is a place of major confrontation between the people and the government security forces, resulting in extra-judicial executions, arbitrary detentions, and forceful eviction. Thus the people have the feeling of being suppressed and shortchanged by the government that supposed to come to their aids in building up their resilience through infrastructure and capacity development. Therefore, the perceived hope (resilience) the victims of environmental degradations have against oil multinational and government for offenses committed by them is to sabotage or targeted protest at oil company activities; incidents of hostage taking; closures or bombing of flow stations; and harassment of oil workers or general public.

Table 4 Perceived consequences of climate change on Livelihood

\begin{tabular}{|c|c|c|c|c|c|c|}
\hline \multirow[t]{2}{*}{ Questions } & \multicolumn{2}{|c|}{ Ibeno } & \multicolumn{4}{|c|}{ Onna } \\
\hline & Sum & Mean & Decision & Sum & Mean & Decision \\
\hline Fish catch & 37 & 1.85 & Disagree & 28 & 1.40 & Disagree \\
\hline Fishing distance & 49 & 2.45 & Agree & 58 & 2.90 & Agree \\
\hline Fish diversity & 32 & 1.60 & Disagree & 24 & 1.20 & Disagree \\
\hline Fishing time & 47 & 2.35 & Agree & 34 & 1.70 & Disagree \\
\hline Fishing effort & 46 & 2.30 & Agree & 40 & 2.00 & No change \\
\hline Structural damage on camp & 51 & 2.55 & Agree & 35 & 1.75 & Disagree \\
\hline Wide spread poverty & 53 & 2.65 & Agree & 58 & 2.90 & Agree \\
\hline New health problems & 33 & 1.65 & Disagree & 40 & 2.00 & Agree \\
\hline Post-harvest loss & 36 & 1.80 & Disagree & 50 & 2.50 & Agree \\
\hline Frequency of fishing & 45 & 2.25 & Agree & 43 & 2.15 & Agree \\
\hline Boat repair/ boat loss & 47 & 2.35 & Disagree & 46 & 2.30 & Agree \\
\hline Damage to nets/net loss & 46 & 2.30 & Disagree & 46 & 2.30 & Agree \\
\hline Labour cost & 52 & 2.60 & Agree & 39 & 1.95 & Disagree \\
\hline Bargaining power & 38 & 1.90 & Disagree & 43 & 2.15 & Agree \\
\hline Restriction on activities & 41 & 2.05 & Agree & 40 & 2.00 & Agree \\
\hline Disappearance of species & 52 & 2.60 & Agree & 45 & 2.25 & Agree \\
\hline Prevalence of sickness & 45 & 2.25 & Agree & 42 & 2.10 & Agree \\
\hline
\end{tabular}

\subsection{Way forward}

According to Rodin and Garris [9] resilience is the ability to recover and at the same time to enhance the capacities of the community or organization to better cope with future stresses. While there is no standard approach to enhance resilience in coastal communities; resilience constantly evolves as new information becomes available and needs become clearer. For the communities to cope in the face of climate change, it requires cooperation among the people, 
developers, government and non-governmental organizations in pollution prevention, infrastructural development and exchange of relevant information.

Several laws and policies in Nigeria have been taken in pollution prevention at the national levels. In addition, Nigeria is a signatory to several international environmental and human rights instruments aimed at promoting fundamental human rights and securing quality life including healthy environment for the Nigerian people. The law has clearly designed environmental authorities or agencies of government with the sole power to enforce environmental laws and standards. However, enforcement of these laws in Niger Delta has been a problem. More so, non-compliance of environmental standards by developers and government's inaction in the implementation of environmental laws has increased the vulnerability of these communities. Without the social and health infrastructures that will help them build up their adaptation; the impact of climate change will overwhelm them. For a cleaner and safer Niger delta environment for all generations; our environmental statutes should be amended to encourage private litigation actions to remedy public environmental wrongs. These communities are often unaware of these environmental law and Nigeria constitutions. Knowledge of the law and legal steps is essential if communities are to take full advantage of their environmental rights. NGOs and organized civil societies in the region should intensify their effort in making the laws and procedures easier to understand and readily accessible. This can be done through organizing awareness programme, using the local media and translating these laws into the indigenous languages.

The government should be made accountable to the people they govern and release funding for putting identified basic infrastructure in place. These infrastructures are part of the assets identified in sustainable livelihood framework of Department for International Development (DFID), [10]. Access to basic amenities and adaptive capacity of livelihood strategies has been used in determining vulnerability $[12,13]$. The more they have access to these livelihood assets the better they will be in coping with the present situation.

The coastal dwellers are often not part of the processes of environmental regulation by the government. Where collective decision making about priorities and project siting should be taken; the communities should be a part in influencing the conditions that affect their lives. Assigning some roles to the local representatives and traditional heads from this region should be encouraged.

\section{Conclusion}

The effect of climate change in coastal communities in Niger delta has been compounded by Oil pollution and environmental degradation associated with exploitation and production of petroleum resources due to the unsustainable operations of the oil companies and the ineffective enforcement of environmental laws and policies by government. This has great impact on the bio-physical environment, human health and safety, and socio-economic in the Niger Delta. Thus there is need for the government and oil companies to adopt environmental friendly approach that will minimize the associated environmental pollution. For resilience of the coastal communities to be enhanced; there is need to put the basic infrastructures in place to protect the environment, their health and means of livelihood; have responsive government and access to laws and regulatory related information.

\section{Compliance with ethical standards}

\section{Acknowledgments}

The author would like to thank the Center for Marine Pollution Monitoring and Seafood Safety and Department of Animal and Environmental Biology, University of Port Harcourt for their supports on the research.

\section{Disclosure of conflict of interest}

There is no conflict of interest.

\section{Statement of informed consent}

Informed consent was obtained from all individual participants included in the study. 


\section{References}

[1] Doust H. (1990). Petroleum geology of the Niger Delta. Geological Society, London, Special Publications, 50 (1), 365-365.

[2] Haack RC, Sundararaman P, Diedjomahor JO, Xiao H, Gant NJ, May ED and Kelsch K. (2000). Niger Delta Petroleum Systems, Nigeria: In Mello MR and Katz BJ. (Eds), Petroleum Systems of South Atlantic Margins: AAPG Memoir 73, American Association of Petroleum Geologists (AAPG), 213-231.

[3] Powell CB, White SA, Ibiebele DO, Bara M, DutKwicz B, Isoun M and Oteogbu FU. (1985). Oshika Oil Spill Environmental Impact; effect on Aquatic biology. Paper presented at NNPC/FMHE International Seminar on petroleum industry and the Nigerian Environment, Kaduna, Nigeria, 168-178.

[4] Awosika LF. (1995). Impacts of global climate change and sea level rise on Coastal resources and energy development in Nigeria. In: Umolu JC. (Ed), Global Climate Change: Impact on Energy Development. DAMTECH Nigeria Limited, Nigeria.

[5] CLO, Civil Liberties Organization. (2002). Blood Trail: Repression and Resistance in the Niger Delta, Country Analysis Brief. Ikeja. Nigeria.

[6] Anifowose B. (2008).Assessing the Impact of Oil and Gas Transport on Nigeria's Environment.U21 Postgraduate Research Conference Proceedings. University of Birmingham UK. .

[7] Chinweze C and Abiol-Oloke G. (2009).Women Issues, Poverty and Social Challenges of Climate Changes in the Nigerian Niger Delta Context.7th International Conference on the Human Dimension of Global Environmental Changes, UN Campus, Bonn, Germany.

[8] Adger WN. (2000). Social and ecological resilience: are they related? Progress in Human Geography, 24(3), 347364 .

[9] Rodin J and Garris R. (2012).Reconsidering Resilience for the 21st Century. In: Shah R and Radelet S. (Eds), USAID Frontiers in Development, Washington, DC, 110-116.

[10] Department for International Development (DFID). (1999). Sustainable livelihoods guidance sheets. London: DFID.

[11] Vincent K and Cull T. (2010). A household social vulnerability index (HSVI) for evaluating adaptation projects in developing countries. In PEGNet Conference 2010: Policies to foster and sustain equitable development in times of crises. Midrand, 16, 2-3

[12] Vincent-Akpu IF and Annor-Frempong F. (2017).Social Vulnerability of Small Scale Coastal Fisher's Livelihood to Climate Change. International Journal of Human Capital and Urban Management, 2(3), 171-180.

\section{How to cite this article}

Vincent-Akpu IF. (2020). Climate change and coping strategies of Ibeno and Onna coastal fishing communities in Niger Delta, Nigeria. GSC Biological and Pharmaceutical Sciences, 10(3), 45-52. 